\title{
Bioengineering for Stem Cell-Based Cardiac Regeneration
}

\section{Hidetoshi Masumoto ${ }^{1,2}$ and Bradley B Keller ${ }^{1,3 *}$}

${ }^{1}$ Kosair Charities Pediatric Heart Research Program, Cardiovascular Innovation Institute, University of Louisville, Louisville, Kentucky, USA

${ }^{2}$ Department of Cardiovascular Surgery, Kyoto University Graduate School of Medicine, Kyoto, Japan

${ }^{3}$ Department of Pediatrics, University of Louisville, Louisville, Kentucky, USA

Cardiovascular disease remains the leading cause of death worldwide. A boundary for conventional severe heart failure treatments exists in spite of significant advances in therapeutic modalities and risk-reduction strategies [1]. This health problem has prompted research into new therapeutic approaches including cardiac regeneration [2]. With the discovery of various stem cell populations possessing cardiogenic potential, and the subsequent ability to isolate and expand these cells, the notion of a stem cell-based regenerative therapy has begun to take shape [3].

Acute ischemic injury and chronic cardiomyopathies lead to permanent loss of cardiac tissue leading to heart failure and a high rate of morbidity and mortality. For these pathologic conditions, cell transplantation is thought to be an emerging therapeutic method for replacing lost myocardium, and stem cell research and clinical trials for cardiac cell therapy are now being prioritized and funded in multiple countries [4,5]. Many clinical studies have been conducted using these somatic stem cells so far: TOPCAREAMI [6], BOOST [7], REPAIR-AMI [8] (Bone marrow hematopoietic stem cells), REGENT [9] (endothelial progenitor cells), POSEIDON [10] (mesenchymal stem cells), MAGIC [11], CAuSMIC [12] (skeletal myoblasts), CADUCEUS [13], SCIPIO5 (cardiac progenitor/stem cells) and so on. However, this field still lacks sufficiently conclusive results to support full-scale implementation of such therapies. A major reason for the insufficient results would be the poor survival and long-term engraftment of transplanted cells. Despite initial positive results on myocardial function and perfusion, the disappearance of transplanted cells reduces the likelihood of sustained positive paracrine effects or sustained recovery of function [14]. It is reported that more than $70 \%$ of the cells die during the first 48 hours after needle injection due to the hypoxic, inflammatory, and/or fibrotic environment [15]. Thus, new strategies such as combination of cardiac cells with bioengineering techniques are being subjected to intense research, suggesting that the strategies may improve the efficiency of stem cell therapies $[16,17]$.

Initial experiments were performed by combining the cells with injectable biomaterials such as collagen, fibrin, gelatin, or Matrigel with the goal of providing a favorable microenvironment rich in growth factors. These early studies showed an increased survival of the grafted cells and an improvement of the cardiac function after transplantation [18-21]. However, these approaches did not accomplish the goal of sustained cell retention or an adequate distribution of the grafted cells. The creation of cellular patches as a tissue-like structure has been developed by using biomaterials which act as a delivery platform for the cells, assuring their engraftment and more homogeneous and organized distribution of the cells [17]. Cellular patches using mesenchymal stem cells (MSCs) entrapped in a collagen-I matrix and transplanted onto rat infarcted hearts induced an increase of cell engraftment and a functional improvement [22]. Three-dimensional (3D) contractile loops of mixed collagen and neonatal cardiomyocytes (CMs) have also been successfully used in rodent cardiac repair experiments. Implantation of these engineered heart tissues onto the damaged heart improved contractile function [23]. We have developed a novel 3D engineered cardiac tissue (ECT) using chick or rat embryonic/fetal/ neonatal CMs and scaffolds as a robust in vitro model to investigate the maturing embryonic myocardium $[24,25]$. Recently, we found that mechanical stretch or p38 mitogen-activated protein kinase inhibition affects cellular development, growth or proliferation using gene expression assays with rat embryonic ECTs [26]. On the other hand, porous biomaterials, such as alginate or polymers like poly-glycolidecolactide, have also been tested as cell scaffolds with human embryonic stem (ES) cell-derived CMs [27]. New strategies like microtemplating or electrospinning have also been incorporated to create scaffolds that mimic the natural heart extracellular matrices to control a homogenous seeding of the cells allowing an organized and aligned distribution [28]. The repopulation of a decellularized mouse heart as extracellular matrices of the whole heart with human induced pluripotent stem cell (iPSC)-derived cardiovascular progenitor cells has also been reported [29].

Another promising approach for construction of 3D tissue-like structure is the creation of cell sheets or patches without scaffold support. The generation of cell sheets using monolayer cell culture is a promising method because of larger scalability and accessibility. This technique can be used with a culture dish covalently grafted with temperature-responsive polymer poly ( $\mathrm{N}$-isopropylacrylamide) (PIPAAm) which enables the preparation of cell sheets without enzymatic digestion [30]. The beneficial potential of this technique has been demonstrated by many experiments using stem cell sources such as the transplantation of a monolayer cell sheet generated from iPSCs or adipose tissue-derived MSCs to animal myocardial infarction models $[31,32]$. We have reported a transplantation study of a threelayered cardiac tissue sheet bioengineered with mouse embryonic stem cell (ESC)-derived defined cardiac cell populations to an infarcted rat heart [33]. In these cases, an increase in neovascularization together with an attenuation of ventricular remodeling responsible for the improvement in cardiac function has been demonstrated and this cell sheet-based method creates a novel platform for exploring the cellular mechanisms of cardiac regeneration. The combinations of cell types composing the transplanted cell sheets enabled us to elucidate the regenerative function of each cell type (for example, the comparison of cell sheets with or without CMs is helpful for the elucidation of

*Corresponding author: Bradley B. Keller, MD, Kosair Charities Pediatric Heart Research Program, Cardiovascular Innovation Institute, University of Louisville, Louisville, Kentucky, 302 East Muhammad Ali Blvd, Louisville, KY 40202, USA, Tel: 502-852-5809; Fax: 502-852-7195; E-mail: Brad.Keller@louisville.edu

Received March 18, 2014; Accepted April 26, 2014; Published April 28, 2014

Citation: Masumoto H, Keller BB (2014) Bioengineering for Stem Cell-Based Cardiac Regeneration. J Stem Cell Res Ther 4: 200. doi:10.4172/21577633.1000200

Copyright: (c) 2014 Masumoto $\mathrm{H}$, et al. This is an open-access article distributed under the terms of the Creative Commons Attribution License, which permits unrestricted use, distribution, and reproduction in any medium, provided the original author and source are credited. 
the cellular function of CMs). This cell-type controlled analysis led us to identify one of the cellular mechanisms of cardiac regeneration following cell therapy that CMs are main contributors for the functional improvement through neovascularization.

Nevertheless the progresses in bioengineered technologies toward cardiac stem cell therapy introduced here, hurdles still remain for producing and adequate quantity of functional cardiac cells which do not die following implantation and for creating patches/organs that can mimic the structure and function of the heart. In this regard, iPSCs possess great potential for cardiac regeneration. A main reason is that iPSCs can be expanded geometrically in vitro while remaining pluripotent in an undifferentiated state in culture, and can give rise to most somatic cell lineages including various cardiac cells once allowed to differentiate [34]. In this regard, the regenerative capacity is theoretically limitless [35]. The merit of iPSCs is larger especially for the heart compared to other organs, such as endocrine or sensory organs, as the heart functions as an assembly of a large number of cells including CMs and other cell types (e.g. vascular cells, cardiac fibroblasts), and numerous heart-composing cells might be required to fully compensate for the damaged human heart [36]. Potent differentiation methods based on high-density monolayer culture and chemically defined factors, and modifications thereof, have been reported to induce CMs from human iPSCs with a robust efficiency of $40-70 \%[37,38]$. The application of these methods would strongly promote cardiac regeneration using human iPSCs. Another advantage of iPSCs is that they lack the ethical and immunogenic issues associated with the use of ESCs [4]. The generation of iPSCs by reprogramming autologous somatic cells with genes regulating pluripotency may resolve the ethical and immunogenic issues associated with the use of ESCs which is brought from inner cell mass with destruction of fertilized egg. Integration of bioengineering and iPSC technologies may generate an ideal structure suitable for cardiac regenerative therapy in the future.

The combination of cell therapy and local administration of cytokines that induce paracrine effects such as angiogenesis is a method for enhancing therapeutic potential of cell therapy. Tabata et al. [39] have developed a bioengineered system for sustained release of angiogenic cytokines, such as basic fibroblast growth factor (bFGF), from a biodegradable material, gelatin hydrogel; this system enables to control the release of cytokines over the periods required for efficient clinical outcomes. The addition of such sustained release of bFGF enhanced the functional benefit of the transplantation of cardiac progenitor cells in a porcine myocardial infarction (MI) model [40].

Besides cell-based strategy, there are promising approaches for cardiac regeneration with bioengineered technologies. Gene therapy is emerging as a potential treatment option in patients suffering from a wide spectrum of cardiovascular diseases [41]. Gene therapy, which is the direct introduction of transgenes into the vasculature or myocardium, may contribute in controlling the symptoms of cardiovascular diseases and may also reverse the pathological conditions involved. In 2010, Ieda et al. [42] reported that a combination of 3 developmental transcription factors (Gata4, Mef2c, and Tbx5) rapidly, efficiently, and directly reprogrammed postnatal cardiac or dermal fibroblasts into differentiated cardiomyocyte-like cells in vitro (direct reprogramming). This technology was recently applied to an in vivo mouse MI model in which the 3 genes were delivered by a retroviral vector, resulting in direct reprogramming of cardiac fibroblasts within the infarction site into cardiomyocyte-like cells and amelioration of cardiac dysfunction [43]. Three goals must be accomplished for appropriate gene therapy: suitable vectors must be generated, a suitable gene or group of genes must be identified, and an appropriate delivery system must be developed. Bioengineered materials such as biodegradable hydrogel are reported to contribute to this appropriate delivery of vectors and enhance the transfection efficiency with sustained release of vectors [44]. Thus, there a range of cellular and tissue engineering strategies are rapidly transitioning from pre-clinical to clinical trials to repair and regenerate damaged myocardium towards sustained recovery. We sincerely expect that these advanced modalities that integrate cellular and bioengineering technologies will enhance the efficacy of cardiac cell therapy and further contribute to cardiac regenerative medicine.

\section{Acknowledgments}

Source of funding: Kosair Charities Pediatric Heart Research Endowment University of Louisville Research Foundation.

\section{References}

1. Ford ES, Capewell S (2011) Proportion of the Decline in Cardiovascular Mortality Disease due to Prevention Versus Treatment: Public Health Versus Clinical Care. Annu Rev Public Health 32: 5-22.[PubMed]

2. Chien KR (2008) Regenerative medicine and human models of human disease. Nature 453(7193): 302-305.[PubMed]

3. Sanganalmath SK, Bolli R (2013) Cell therapy for heart failure: a comprehensive overview of experimental and clinical studies, current challenges, and future directions. Circ Res 113(6): 810-834.[PubMed]

4. Joggerst SJ, Hatzopoulos AK (2009) Stem cell therapy for cardiac repair: benefits and barriers. Expert Rev Mol Med 11: e20.[PubMed]

5. Bolli R, Chugh AR, D'Amario D, Loughran JH, Stoddard MF, et al. (2011) Cardiac stem cells in patients with ischaemic cardiomyopathy (SCIPIO): initial results of a randomised phase 1 trial. The Lancet 378(9806): 1847-1857. [PubMed]

6. Leistner DM, Fischer-Rasokat U, Honold J, Seeger FH, Schächinger V, et al (2011) Transplantation of progenitor cells and regeneration enhancement in acute myocardial infarction (TOPCARE-AMI): final 5-year results suggest longterm safety and efficacy. Clin Res Cardiol 100(10): 925-934.[PubMed]

7. Meyer GP, Wollert KC, Lotz J, Pirr J, Rager U, et al. (2009) Intracoronary bone marrow cell transfer after myocardial infarction: 5-year follow-up from the randomized-controlled BOOST trial. Eur Heart J 30(24): 2978-2984.[PubMed]

8. Assmus B, Rolf A, Erbs S, Elsässer A, Haberbosch W, et al. (2010) Clinical outcome 2 years after intracoronary administration of bone marrow-derived progenitor cells in acute myocardial infarction. Circ Heart Fail 3: 89-96.[PubMed]

9. Tendera M, Wojakowski W, Ruzyłło W, Chojnowska L, Kepka C, et al. (2009) Intracoronary infusion of bone marrow-derived selected CD34+CXCR4+ cells and non-selected mononuclear cells in patients with acute STEMI and reduced left ventricular ejection fraction: results of randomized, multicentre Myocardia Regeneration by Intracoronary Infusion of Selected Population of Stem Cells in Acute Myocardial Infarction (REGENT) Trial. Eur Heart J 30(11): 1313-1321. [PubMed]

10. Suncion VY, Ghersin E, Fishman JE, Zambrano JP, Karantalis V, et al (2014) Does Transendocardial Injection of Mesenchymal Stem Cells Improve Myocardial Function Locally or Globally? An Analysis From the POSEIDON Randomized Trial. Circ Res 114(8): 1292-301.[PubMed]

11. Menasche $P$, Alfieri $O$, Janssens $S$, McKenna W, Reichenspurner $H$, et al (2008) The Myoblast Autologous Grafting in Ischemic Cardiomyopathy (MAGIC) trial: first randomized placebo-controlled study of myoblast transplantation. Circulation 117(9): 1189-1200.[PubMed]

12. Dib N, Dinsmore J, Lababidi Z, White B, Moravec S, et al. (2009) One-year follow-up of feasibility and safety of the first U.S., randomized, controlled study using 3-dimensional guided catheter-based delivery of autologous skeletal myoblasts for ischemic cardiomyopathy (CAuSMIC study). JACC Cardiovasc Interv 2(1): 9-16.[PubMed]

13. Makkar RR, Smith RR, Cheng K, Malliaras K, Thomson LE, et al. (2012) Intracoronary cardiosphere-derived cells for heart regeneration after myocardial infarction (CADUCEUS): a prospective, randomised phase 1 trial. The Lancet 379(9819): 895-904.[PubMed] 
14. Pelacho B, Mazo M, Gavira JJ, Prosper F (2011) Adult stem cells: from new cell sources to changes in methodology. J Cardiovasc Transl Res 4(2): 154-160. [PubMed]

15. Muller-Ehmsen J, Whittaker P, Kloner RA, Dow JS, Sakoda T, et al. (2002) Survival and development of neonatal rat cardiomyocytes transplanted into adult myocardium. J Mol Cell Cardiol 34(2): 107-116.[PubMed]

16. Masumoto H, Yamashita JK (2013) Strategies in cell therapy for cardiac regeneration. Inflammation and Regeneration 33: 114-120.

17. Ye L, Zimmermann WH, Garry DJ, Zhang J (2013) Patching the heart: cardiac repair from within and outside. Circ Res 113(7): 922-932.[PubMed]

18. Cortes-Morichetti M, Frati G, Schussler O, Duong Van Huyen JP, et al. (2007) Association between a cell-seeded collagen matrix and cellular cardiomyoplasty for myocardial support and regeneration. Tissue Eng 13(11): 2681-2687.[PubMed]

19. Ryu JH, Kim IK, Cho SW, Cho MC, Hwang KK, et al. (2005) Implantation of bone marrow mononuclear cells using injectable fibrin matrix enhances neovascularization in infarcted myocardium. Biomaterials 26(3): 319-326. [PubMed]

20. Smith RR, Marban E, Marban L (2013) Enhancing retention and efficacy of cardiosphere-derived cells administered after myocardial infarction using a hyaluronan-gelatin hydrogel. Biomatter 3(1): e24490.[PubMed]

21. Ou LL, Li W, Zhang Y, Wang W, Liu J, et al. (2011) Intracardiac injection of matrigel induces stem cell recruitment and improves cardiac functions in a rat myocardial infarction model. J Cell Mol Med 15(6): 1310-1318.[PubMed]

22. Simpson D, Liu H, Fan TH, Nerem R, Dudley SC Jr. (2007) A tissue engineering approach to progenitor cell delivery results in significant cell engraftment and improved myocardial remodeling. Stem Cells 25(9): 2350-2357.[PubMed]

23. Zimmermann WH, Melnychenko I, Wasmeier G, Didié $\mathrm{M}$, Naito $\mathrm{H}$, et al (2006) Engineered heart tissue grafts improve systolic and diastolic function in infarcted rat hearts. Nat Med 12(4): 452-458.[PubMed]

24. Tobita K, Liu LJ, Janczewski AM, Tinney JP, Nonemaker JM, et al. (2006) Engineered early embryonic cardiac tissue retains proliferative and contractile properties of developing embryonic myocardium. Am J Physiol Heart Circ Physiol 291(4): H1829-1837.[PubMed]

25. Fujimoto KL, Clause KC, Liu LJ, Tinney JP, Verma S, et al. (2011) Engineered fetal cardiac graft preserves its cardiomyocyte proliferation within postinfarcted myocardium and sustains cardiac function. Tissue engineering Part A 17(5-6): 585-596.[PubMed]

26. Ye F, Yuan F, Li X, Cooper N, Tinney JP, et al. (2013) Gene expression profiles in engineered cardiac tissues respond to mechanical loading and inhibition of tyrosine kinases. Physiol Rep 1: e00078.[PubMed]

27. Caspi O, Lesman A, Basevitch Y, Gepstein A, Arbel G, et al. (2007) Tissue engineering of vascularized cardiac muscle from human embryonic stem cells. Circ Res 100(2): 263-272.[PubMed]

28. Madden LR, Mortisen DJ, Sussman EM, Dupras SK, Fugate JA, et al. (2010) Proangiogenic scaffolds as functional templates for cardiac tissue engineering Proc Natl Acad Sci U S A 107(34): 15211-15216.[PubMed]

29. Lu TY, Lin B, Kim J, Sullivan M, Tobita K, et al. (2013) Repopulation of decellularized mouse heart with human induced pluripotent stem cell-derived cardiovascular progenitor cells. Nat Commun 4: 2307.[PubMed]

30. Okano T, Yamada N, Sakai H, Sakurai Y (1993) A Novel Recovery-System for Cultured-Cells Using Plasma-Treated Polystyrene Dishes Grafted with Poly(NIsopropylacrylamide). J Biomed Mater Res 27(10): 1243-1251.[PubMed]
31. Miyahara Y, Nagaya N, Kataoka M, Yanagawa B, Tanaka K, et al. (2006) Monolayered mesenchymal stem cells repair scarred myocardium after myocardial infarction. Nat Med 12: 459-465.[PubMed]

32. Kawamura M, Miyagawa S, Fukushima S, Saito A, Miki K, et al. (2013) Enhanced survival of transplanted human induced pluripotent stem cell-derived cardiomyocytes by the combination of cell sheets with the pedicled omental flap technique in a porcine heart. Circulation 128(11 suppl 1): S87-94.[PubMed]

33. Masumoto H, Matsuo T, Yamamizu K, Uosaki H, Narazaki G, et al. (2012) Pluripotent stem cell-engineered cell sheets reassembled with defined cardiovascular populations ameliorate reduction in infarct heart function through cardiomyocyte-mediated neovascularization. Stem Cells 30: 11961205.[PubMed]

34. Takahashi K, Tanabe K, Ohnuki M, Narita M, Ichisaka T, et al (2007) Induction of pluripotent stem cells from adult human fibroblasts by defined factors. Cell 131(5): 861-872.[PubMed]

35. Murry CE, Keller G (2008) Differentiation of embryonic stem cells to clinically relevant populations: lessons from embryonic development. Cell 132(4): 661680.[PubMed]

36. Masumoto H, Sakata R (2012) Cardiovascular surgery for realization of regenerative medicine. Gen Thorac Cardiovasc Surg 60(11): 744-755. [PubMed]

37. Laflamme MA, Chen KY, Naumova AV, Muskheli V, Fugate JA, et al (2007) Cardiomyocytes derived from human embryonic stem cells in pro-survival factors enhance function of infarcted rat hearts. Nat Biotechnol 25(9): 10151024.[PubMed]

38. Uosaki H, Fukushima H, Takeuchi A, Matsuoka S, Nakatsuji N, et al. (2011) Efficient and Scalable Purification of Cardiomyocytes from Human Embryonic and Induced Pluripotent Stem Cells by VCAM1 Surface Expression. PLoS One 6(8): e23657.[PubMed]

39. Tabata $Y$ (2003) Tissue regeneration based on growth factor release. Tissue Eng 9 Suppl 1: S5-15.[PubMed]

40. Takehara N, Tsutsumi Y, Tateishi K, Ogata T, Tanaka H, et al. (2008) Controlled delivery of basic fibroblast growth factor promotes human cardiosphere-derived cell engraftment to enhance cardiac repair for chronic myocardial infarction. $J$ Am Coll Cardiol 52(23): 1858-1865.[PubMed]

41. Gaffney MM, Hynes SO, Barry F, O’Brien T (2007) Cardiovascular gene therapy: current status and therapeutic potential. Br J Pharmacol 152(2): 175188.[PubMed]

42. leda M, Fu JD, Delgado-Olguin P, Vedantham V, Hayashi Y, et al. (2010) Direct reprogramming of fibroblasts into functional cardiomyocytes by defined factors. Cell 142(3): 375-386.[PubMed]

43. Qian L, Huang Y, Spencer Cl, Foley A, Vedantham V, et al. (2012) In vivo reprogramming of murine cardiac fibroblasts into induced cardiomyocytes. Nature 485(7400): 593-598.[PubMed]

44. Kushibiki T, Tabata Y (2004) A new gene delivery system based on controlled release technology. Current Drug Deliv 1: 153-163.[PubMed] 